\title{
Efficacy of various inert materials against Sitophilus oryzae in sorghum
}

G.R. BHANDERI*, G.G. RADADIYA AND D.R. PATEL

Department of Entomology, N.M. College of Agriculture, Navsari Agricultural University, NAVSARI (GUJARAT) INDIA

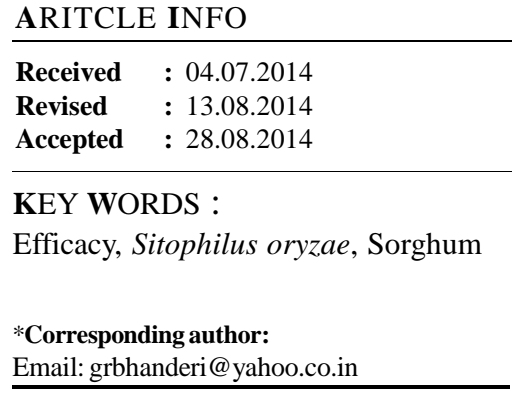

\begin{abstract}
Research study on the screening of sorghum genotypes against rice weevil, Sitophilus oryzae (Linnaeus) on stored sorghum was carried out during the year 2007-08 and 2008-09 at the Main Sorghum Research Station, Navsari Agricultural University, Surat, Gujarat state. The results of study on per cent grain damage and weight loss of grains treated with various plant products revealed that the least grain damage and weight loss were found in grains treated with kaolinite clay 10 per cent and bentonite clay 10 per cent against $S$. oryzae on sorghum.
\end{abstract}

How to view point the article : Bhanderi, G.R., Radadiya, G.G. and Patel, D.R. (2014). Efficacy of various inert materials against Sitophilus oryzae in sorghum. Internat. J. Plant Protec., 7(2) : 389-392. 